AGRO EKONOMI, Vol 30, Issue 1, June 2019, Page.78-93

DOI : http://doi.org/10.22146/ae.46979

ISSN 0215-8787 (print), ISSN 2541-1616 (online)

Available at https://jurnal.ugm.ac.id/jae/

\title{
THE COMPETITIVENESS OF STEVIA REBAUDIANA AS A SWEETENER ALTERNATIVE IN TAWANGMANGU SUBDISTRICT KARANGANYAR REGENCY
}

\author{
Trisna Wahyu Swasdiningrum Putri ${ }^{1}$, Any Suryantini ${ }^{2}$, Arini Wahyu Utami ${ }^{3}$ \\ ${ }^{1}$ Master Student of Agricultural Economics, Faculty of Agriculture, UGM \\ 2,3Faculty of Agriculture, UGM Jl. Flora No. 1 Bulaksumur, Yogyakarta \\ trisnawahyusp18@gmail.com
}

Submitted: 6 June 2019 ; Revised : 10 July 2019 ; Accepted: 8 Agustus 2019

\begin{abstract}
The purpose of this research is to analyze the competitiveness of Stevia agriculture in Tawangmangu Subdistrict, Karanganyar Regency based on its competitive and comparative advantage, as well as to know the effect of government policies on this agricultural product. The basic method used was a descriptive analysis with a quantitative approach. The study involved 14 stevia cultivators as respondents. Sampling was carried out by way of census. The data of the study were collected during one stevia planting season in the course of 2015-2018, with an average planting period of 4 years. The data were collected using Policy Analysis Matrix (PAM) method. The results reveal that stevia farming in Tawangmangu Subdistrict is proven to have a competitive advantage as seen from the value of PP and PCR. It also has a comparative advantage as indicated by its SP and DRCR values. The impact of government policy is apparent from (a) the value of EPC and NPCO pinpointing that there is protection from government policy for domestic farmers who cultivate stevia intensively, especially for output (stevia dried leaves) prices. It is also indicated by (b) the value of NPCI highlighting that the tradable input costs paid by farmers are lower than the cost of tradable inputs that should be paid. This is in accordance with the rule of the Minister of Agriculture of the Republic of Indonesia No.47/Permentan/ SR.310/11/2018. It is pivotal that government provides the stevia farmers with stevia superior seeds to boost the production of high-quality stevia product.
\end{abstract}

Keywords: Competitiveness, PAM, Stevia rebaudiana

Putri, T.S, Any, S,. \& Arini, W.U. (2019) The Competitiveness Of Stevia Rebaudiana As A Sweetener Alternative In Tawangmangu Subdistrict Of Karanganyar Regency . Agro Ekonomi 30(1), 78-93.

\section{INTRODUCTION}

Currently Indonesia still heavily relies on sugarcane as the main sweetener despite its low competitiveness (Malian \& Saptana, 2003). In addition to sugarcane-based sweeteners, a vital sweetener species is known as Stevia rebaudiana. This plant species provides many benefits since it may also function as a medicine and has a high commercial value throughout the world (Ahmad et al., 2016). Nowadays, along with the heightening case of obesity and high prevalence of diabetes, there has been 
an increasing demand on the use of Stevia rebaudiana for better diet as a substitute for sugar (Magnuson et al., 2016). Stevia rebaudiana is a sweetening vegetal originating from Paraguay and currently has been spreading to several Asian, European and Canadian countries. Stevia leaves contain stevioside with a sweetness level of 200 to 300 times higher than cane sugar or sucrose. Stevia contains non-fermented sweetening compounds which are low in calories, does not cause gene mutation, does not cause congenital defect, and is not carcinogenic or causes cancer (LemusMondaca et al., 2012).

One of the most necessary and popular sweetener plants in some countries, both developing and developed countries is Stevia rebaudiana. It has high potential as a sweetener, antitoxic (Yadav et al., 2011). Stevia's global market development continues to increase year by year, from 2,750 tons in 2009 to 7,150 tons in 2017 (Hembrough, 2011; Redwood \& Crossland, 2014). The increasing supply of stevia on the global market indicates that there has been a soaring use of stevia as a sugar substitute product (Magnuson et al., 2016). This increasing trend will benefit farmers who intensively cultivate stevia. Research conducted by Nordiana et al. (2016) shows that the estimated profit of stevia per acre for each planting time is much higher than sugarcane cultivation, which respectively is RM 46,000 for stevia and RM 6,200 for sugarcane.

Indonesia, however, notes a relatively low level of stevia plant cultivation as one of the healthy natural sweetening commodities. The lack of information related to its planting technical standards, especially seedling multiplication, has led to low-quality product (Djajadi, 2014). The bitter taste in leaf extract is also an obstacle in the development of stevia in Indonesia (Purwadi et al., 2010). Moreover, the lack of farmers' interest in cultivating stevia and low level of interest among many investors or companies in developing a large scale stevia planting have resulted in less extensive stevia market in Indonesia. Another factor why some farmers do not cultivate stevia is an inadequate environment, for example the land is full of coffee plants and timber and most of them are steep areas (Sukayat et al., 2018). In fact, without intensive stevia cultivation, the product will have low competitiveness.

There are only a few empirical studies addressing the competitiveness of stevia sweetener since most studies concern in the competitiveness of sugarcane commodities as the main sweetener. Nurjanah et al., (2018) revealed that sugarcane farming in Bantul has competitiveness based on its competitive advantage and comparative advantage. This result 
is in accordance with that of Abdalla Emam \& Musa (2011) from the research article about the competitiveness of sugar cane in Sudan, case study at the Kenana Sugar Company. However, the previous results are slightly different from what was revealed by Saputro et al. (2017) stating that sugarcane agriculture in East and Central Java Provinces has competitiveness seen from competitive excellence, but does not have a comparative advantage. On the other hand, the current study introduces a novel commodity, Stevia rebaudiana, as an alternative sweetener product in Indonesia with the aspect of competitiveness that has never been examined by the previous researches.

The significance of this research lies in good market opportunities and wider benefits that the product offers than that offered by other sweeteners in general. In other words, there is a good prospect in developing stevia farm as an alternative sweetener product in Indonesia, especially in Tawangmangu Subdistrict, Karanganyar Regency. The purpose of this research is to find out the competitiveness of Stevia agriculture in Tawangmangu Subdistrict, Karanganyar Regency based on its competitive and comparative advantage, as well as to know the impact of government policies on this agricultural product.

\section{METHODS}

In this study, descriptive analysis method with quantitative approach was used as the basic method. It systematically and factually describes facts and the relationships between variables investigated by collecting data, processing, analyzing, and interpreting data in hypothesis testing. The primary and secondary data were elicited. Primary data were obtained through some questionnaire-based interviews and through respondents' observations conducted in April 2019 for one stevia planting season for 4 years (20152018). Secondary data were obtained from recording documents or reports of relevant agencies. Some secondary data in this study included exportand import data from the Central Statistics Agency (www. bps.go.id), transportation costs derived from expeditions (for example, FEDEX), currency exchange data collected from the Ministry of Commerce of the Republic of Indonesia (www.kemendag.go.id), and other supporting resources. The research location samples were selected purposively in the stevia cultivation center in Tawangmangu Subdistrict, Karanganyar Regency. Around the 1990s, since the stevia business in Indonesia went bankrupt, stevia cultivation only existed in the Tawangmangu Subdistrict, Karanganyar Regency with a small scale of business to meet the needs of the 
herbal medicine industry. Geographically, Tawangmangu Subdistrict, Karanganyar Regency has suitable conditions to be used as a development area for stevia in Indonesia. Data about farming and stevia farmers were not yet available, both at agriculture department and BPS. Sampling was carried out by way of census, by involving 14 stevia farmers in Tawangmangu Subdistrict, Karanganyar Regency as respondents. Stevia farmers' census data was obtained from collectors, residents, and fellow farmers. Stevia cultivators were the respondents in this research, because their understanding about the output produced from the inputs used was considerable.

\section{Method of Analysis}

The collected data were analysed by PAM (Policy Analysis Matrix). PAM is a tool to analyze the influence of government intervention and the impact on commodity systems, and their influence on the competitiveness of a commodity. The preparation stages of the PAM tables are as follows (Monke \& Pearson, 1989):

1) Identifying all inputs utilized in the production process.

2) Distributing tradable inputs and non-tradable inputs.

3) Estimating the shadow prices of inputs, outputs, and exchange rates.

4) Analyzing comparativeand competitive advantages and the impact of policies with the PAM model.

Table 2 indicates that the initial line of the PAM matrix is the estimation of the private price or market price, which is the price actually be accepted by the farmer. The second row is an estimation based on social price (shadow price),

Table 1. Determining Allocation of Production Costs into Domestic and Foreign Components

\begin{tabular}{|c|c|c|c|}
\hline No & Component & Domestic (\%) & Foreign (\%) \\
\hline 1 & Seeds & 100.00 & 0.00 \\
\hline 2 & Manure & 100.00 & 0.00 \\
\hline 3 & Compost fertilizer & 100.00 & 0.00 \\
\hline 4 & Urea fertilizer & $100.00^{*}$ & $0.00^{*}$ \\
\hline 5 & SP-36 fertilizer & $52.29^{*}$ & $47.71^{*}$ \\
\hline 6 & NPK-Phonska fertilizer & $45.55^{*}$ & $54.45^{*}$ \\
\hline 7 & Pesticides & $64.00^{* *}$ & $36.00^{* *}$ \\
\hline 8 & Workforce & 100.00 & 0.00 \\
\hline 9 & Land rent & 100.00 & 0.00 \\
\hline 10 & Equipment depreciation & 100.00 & 0.00 \\
\hline 11 & Other costs & 100.00 & 0.00 \\
\hline
\end{tabular}

Source: APPI* (2019); BPS** (2009) 
Table 2. Policy Analysis Matrix (PAM)

\begin{tabular}{lcccc}
\hline \multirow{2}{*}{ Description } & Revenue & \multicolumn{2}{c}{ Cost } & \multirow{2}{*}{ Profit } \\
\cline { 3 - 4 } & & Tradable Input & $\begin{array}{c}\text { Non tradable } \\
\text { Input }\end{array}$ & \\
\hline Private Price & A & B & C & D = A - B - C \\
Social Price & E & F & G & H = E - F - G \\
Policy Impact & I = A - E & J = B - F & K = C - G & L = D - H = I - J - K \\
\hline
\end{tabular}

Source: Monke \& Pearson, 1989

Description:

A: Stevia farm revenue at private prices (IDR/ $\mathrm{m}^{2}$ )

B: Total tradable input for stevia farming at private prices (IDR/ $\mathrm{m}^{2}$ )

C: Total non-tradable input costs for stevia farming at private prices (IDR/ $\mathrm{m}^{2}$ )

D: Profit rate on private prices (IDR $/ \mathrm{m}^{2}$ )

E: Stevia farm revenue at social prices (IDR $/ \mathrm{m}^{2}$ )

F: Total tradable costs for stevia farming at social prices (IDR/ $\mathrm{m}^{2}$ )

G: Total non-tradable input costs for stevia farming at social prices (IDR/ $\mathrm{m}^{2}$ )

$\mathrm{H}$ : Social profit (IDR $/ \mathrm{m}^{2}$ )

I: Output Transfer (OT)

J: Input Transfer (IT)

K: Transfer factor (TF) (IDR/ $\left.\mathrm{m}^{2}\right)$

L: Net transfer (NT) (IDR $\left./ \mathrm{m}^{2}\right)$

which is a price representing the real economic or social value for the elements of cost and outcome (prices that produce the best distribution of resources and automatically produce the highest revenue). The third line is the difference in the calculation of private prices with social prices as a result of the effect of government policies.

The competitive advantage of a commodity is indicated by the value of Private Profitability (PP) and the value of the Private Cost Ratio (PCR). The positive private profitability $(\mathrm{PP}>0)$ indicates that commodity is financially profitable. When the PCR is less than 1 , the farm is competitive (Akhtar et al., 2016).
The comparative advantage of a commodity is apparent from the indicators of the value of social profit or Social Profitability (SP) and the value of the Domestic Resource Cost Ratio (DRCR). The positive social profit ( $\mathrm{SP}>0$ ) indicates that commodity is economically profitable. When the DRCR value is less than 1 , indicating that commodity is economically advantageous (Akhtar et al., 2016).

The exchange rate of USD to IDR of this study refers to the exchange rate in 2019. The determination of the shadow price of the exchange rate or SER is as follows (Gittinger, 1986). 


$$
\begin{aligned}
& S C F_{t}=\frac{X_{t}+M_{t}}{\left(X_{t}-T_{x t}\right)+\left(M_{t}+T_{m t}\right)} \\
& S E R=\frac{O E R}{S C F_{t}}
\end{aligned}
$$

Description:

$\mathrm{SCF}^{\mathrm{t}}=$ Standard conversion factor for year $\mathrm{t}$

$\mathrm{X}^{\mathrm{t}}=$ Indonesian's exports value for year $t(\mathrm{Rp})$

$\mathrm{M}^{\mathrm{t}}$ = Indonesia's import value for year $\mathrm{t}(\mathrm{Rp})$

$\mathrm{Tm}^{\mathrm{t}}=$ Value of $\mathrm{t}$-year import tax (Rp)

$\mathrm{Tx}^{\mathrm{t}}=$ Value of $\mathrm{t}$-year export tax (Rp)

SER = Shadow exchange rate $(\mathrm{Rp} / \mathrm{US}$ \$)

OER = Official exchange rate (Rp / US \$)

\section{RESULTS AND DISCUSSION}

\section{Policy Analysis Matrix (PAM)}

The competitiveness of stevia farming in Tawangmangu Subdistrict, Karanganyar Regency was analyzed by firstly looking at the production input prices and the production costs of stevia farming. Afterwards, the Policy Analysis Matrix (PAM) method was used to estimate the competitiveness of stevia farming in Tawangmangu Subdistrict of Karanganyar Regency. The PAM table presented in Table 3 describes all data resulted from the input output structure at the farm level. The calculation of these elements results in financial and economic benefits, and reveals the impact of policies which should be applied by the government both for input, output, and input and output, which can be used to explain the competitiveness of the commodity (Monke \& Pearson, 1989).

\section{Competitive Analysis of Stevia rebaudiana Farming in Tawangmangu Subdistrict, Karanganyar Regency}

The competitive advantage is an advantage that is not easily copied, so that it can be maintained over a long period of time (Kurniawan \& Budhi, 2017).The competitive advantage of a commodity is indicated by the value of Private Profitability (PP) and the value of the Private Cost Ratio (PCR). These indicators are useful for showing the financial benefits of a commodity and the

Table 3. PAM of Stevia Farming in Tawangmangu Subdistrict, Karanganyar Regency in 2015-2018

\begin{tabular}{lrrrr}
\hline \multirow{2}{*}{ Description } & \multirow{2}{*}{ Revenue } & \multicolumn{2}{c}{ Input } & \multirow{2}{*}{ Profit } \\
\cline { 3 - 4 } & & Tradable & Non Tradable & \\
\hline Private Price & $172,436,693$ & $2,566,591$ & $37,094,364$ & $132,775,738$ \\
Social Price & $85,728,902$ & $3,801,974$ & $39,744,552$ & $42,182,376$ \\
Policy Impact & $86,707,791$ & $-1,235,383$ & $-2,650,188$ & $90,593,362$ \\
\hline
\end{tabular}

Source: Primary Data Analysis, 2019 
level of efficiency of resource use. Private Profitability (PP) was gained from the difference between private revenue of Rp. 172,436,693, private tradable input costs of Rp. 2,566,591 and private nontradable input costs of Rp. 37,094,364, resulting in private profitability of Rp. $132,775,738$ (Table 3). The positive private profitability ( $\mathrm{PP}>0$ ) indicates that stevia farming in Tawangmangu Subdistrict, Karanganyar Regency is financially profitable. Therefore, continuity of stevia farming can be maintained.

The efficiency level of resource use can be calculated using the Private Cost Ratio (PCR). When the PCR is less than 1 , the farm is competitive (Akhtar et al., 2016). The PCR value was gained from the cost of private non-tradable input amounting to Rp. 37,094,364 divided by private receipts of Rp. 172,436,693 reduced by private tradable input costs of Rp. 2,566,591 (Table 3), resulting in the PCR value of 0.22 indicating that stevia farming in Tawangmangu Subdistrict, Karanganyar Regency is financially profitable. Farmers were capable to fund their domestic factors at private prices. Value of 0.22 from PCR means that to generate a unit of valueadded output in private prices needs immolate domestic input costs at private prices of 0.22 units. The small value of PCR is due to private income which was greater than the cost of private tradable and non-tradable inputs.

The competitive excellence of stevia farming in Tawangmangu Subdistrict, Karanganyar Regency owned shown by distance between farmers and collectors were relatively close. It caused transport costs incurred by farmers become small or even farmers do not pay for transportation since they transported by themselves without using transportation. This also makes the selling price of stevia cheaper and the product freshness is maintained. In addition, the knowladge obtained by farmers independently, for example from megazines also caused stevia farming to have a competitive excellence.

The competitive excellence possessed by stevia farming is in accordance with the research conducted by Saputro et al. (2017), where sugarcane farming in Central Java has a competitive excellence (PCR $<1$ ), and conducted by Nurjanah et al. (2018), where sugarcane farming in Bantul district has a competitive excellence (PCR $<1$ ). It shows that financially, sugarcane farmings in Central Java and Bantul district were efficient. It indicates that Stevia rebaudiana can be used as an alternative sweetener, considering that stevia has a competitive excellence like sugarcane sweeteners. 


\section{Comparative Advantage Analysis} of Stevia rebaudiana Farming in Tawangmangu Subdistrict, Karanganyar Regency

According to the comparative advantage law, even though a country is less efficient than other countries in producing both commodities, there is still a basis for trading that benefits both parties (Salvatore, 1997). The comparative advantage of a commodity is apparent from the indicators of the value of social profit or Social Profitability (SP) and the value of the Domestic Resource Cost Ratio (DRCR). The social benefit was obtained from the difference between social income of Rp. 85,728,902, social tradable input costs of Rp. 3,801,974 and social non-tradable input costs of Rp. 39,744,552, resulting in social profit of Rp. 42,182,376 (Table 3). The positive social profit $(\mathrm{SP}>0$ ) indicates that stevia farming in Tawangmangu Subdistrict, Tawangmangu Regency was economically profitable and worth the effort. The SP value is the nominal obtained if all the stevia produced by the farmer is assumed to be stevia dried leaves and is exported. Farmers will benefit more from selling stevia dried leaves on the international market than in the domestic market. It can be seen that the development of stevia on the international market from year to year continued to increase, from 2,750 tons in 2009 to 5,638 tons in 2016 (Fedor, 2016; Redwood \& Crossland, 2014; Hembrough, 2011). The demand for stevia sugar was expected to increase in the future along with the increasing number of people with diabetes and obesity, people's income, the growth of the food and beverage processing industry, and the increasing public interest in natural products. It shows that stevia had a good market opportunity and marketing activities, which were increasing from target.

DRCR is exerted to know whether economically the domestic resources used in farming have been used efficiently or not (Akhtar et al., 2016). DRCR is the comparison of non-tradable input fees to value-added output from tradable input fees at social prices. The DRCR value obtained from the costs of non-tradable social inputs amounting to Rp. $39,744,552$ was divided by social revenue of Rp. 85,728,902 minus social tradable input costs of Rp. 3,801,974 (Table 3), resulting in the DRCR value of 0.49 . The DRCR value of 0.49 is less than one (DRCR $<1$ ), indicating that stevia farming in Tawangmangu District, Karanganyar Regency was economically advantageous. The DRCR value of 0.49 also means that to generate a unit of output at social prices needs to reduce domestic input costs at social prices of 0.49 units. The small DRCR value is 
resulted from the social revenue that is greater than the fees of social tradable and non-tradable inputs.

The positive value of social profit and the value of DRCR which was less than one shows that stevia farming in the District of Tawangmangu, Karanganyar Regency was economically advantageous and had a comparative excellence. Domestic resources in economic activity of stevia farming had been used efficiently, or in other words, the fulfillment of demand for a domestic commodity was more profitable if it was produced domestically.

One area fulfilling the requirements for stevia growth was Tawangmangu District, Karanganyar Regency. The environment which is suitable to grow conditions is one of the factors causing stevia commodity have a comparative excellence, because stevia can only grow well and generate maximum production in that environment. The comparative excellence that stevia has will cause stevia to sell when marketed.

The comparative excellence possessed by stevia farming is in accordance with the research conducted by Nurjanah et al., (2018), where sugarcane farming in Bantul district had a comparative excellence. Economically sugarcane farming in Bantul was inefficient (DRCR $<1$ ). It indicates that Stevia rebaudiana can be used as an alternative sweetener, considering that stevia has a competitive excellence like sugarcane sweeteners.

The comparative excellence of stevia farming is in contrast to research conducted by Saputro et al. (2017), where sugarcane farming in Central Java does not have a comparative excellence (DRCR > 1). This shows that sugar export activities are not profitable if done by sugarcane farming in Central and East Java Province. It is certainly an added value for stevia farming, where the comparative excellence stevia farming can support the use of Stevia rebaudiana as an alternative sweetener.

\section{Analysis of the Impact of Government Policy \\ Output Policy}

Some of the policies that have been carried out by the government to develop stevia in Indonesia, especially in Tawangmangu Subdistrict, Karanganyar Regency are standarization of plants, clinical trials on stevia by BPOM, and BBPPTOOT had a research garden partly planted with stevia. In addition, the Minister of Health also formalized regulation number 33 of 2012 concering teh use of stevia as a low calorie sweetener ingredient in Indonesia (Edi et al., 2015).

Policies on outputs carried out by the government is indicated by two 
indicators, namely Output Transfer (OT) and Nominal Protection Coefficient on Output (NPCO). Output Transfer (OT) is private revenue minus social revenue. Output Transfer was positive (OT > 0), which was $\mathrm{Rp} 86,707,791$ (Table 3), because of the differences in private prices paid by agriculturists with their social prices. This shows that the private price of output was higher than the social price. Based on the OT value, it can be seen that the government provided protection against the output price of stevia farming in Tawangmangu Subdistrict, Karanganyar Regency. Positive transfers occurred from consumer incentives to farmers, thereby increasing the profit received by farmers. Consumers, in this case were herbal industry, were required to pay the farmers at a price above the social price. This condition benefited stevia farming more than the herbal industry.

Nominal Protection Coefficient on Output (NPCO) shows the difference between domestic prices and social prices. The NPCO value obtained was more than one (NPCO $>1)$, which was equal to 2.01. This means that domestic prices are above the social price. The price of output (stevia dried leaves) received by stevia farmers in Tawangmangu District, Karanganyar Regency is protected by the government. The existence of government protection against the output (stevia dried leaves) of stevia farmers will increase the competitiveness of stevia, where domestic stevia production increase because existing farmers process stevia intensively.

The NPCO value owned by stevia farming was in accordance with research conducted by Nurjanah et al. (2018), where more than one NPCO value (NPCO $>1$ ) of sugar cane agriculture in Bantul was 1.46. This shows that government policies were protective of the output of sugar farming in Bantul regency. The impact of government policies regarding sugar prices benefited producers (farmers) or there were subsidies that could increase income.

\section{Input Policy}

Policies on inputs carried out by the government include subsidies and import constraint to shield farmers. Indicators to find out the availability of government endorsement for inputs can be known from the Input Transfers, Transfer Factors, and Nominal Input Protection Coefficients.

The value of Input Transfer (IT) is costs of private tradable inputs minus costs of social tradable inputs. Input Transfer (IT) of stevia farming in Tawangmangu Subdistrict, Karanganyar Regency was negative (IT $\leq 0$ ), which was $\operatorname{Rp} 1,235,383$ (Table 3). This shows 
the existence of government subsidies on foreign inputs, in accordance with regulation No. 47/ Permentan/SR.310/ 11/ 2018 issued by the Minister of Agriculture of the Republic of Indonesia concerning the distribution and the top price of a single item of subsidized manure in the agricultural sector in the 2019 budget. The concerned subsidized fertilizers were SP-36, NPK, urea, ZA, and organic manure. Stevia farming in Tawangmangu Subdistrict, Karanganyar Regency used government-subsidized tradable inputs, SP-36 and NPK. Hence, stevia farmers did not have to pay in full to buy inputs and pay input costs at prices lower than the price that should be paid.

Transfer factor (TF) is the difference between private non-tradable input costs and social non-tradable input costs. Transfer factor (FT) in stevia farming in Tawangmangu Subdistrict, Karanganyar Regency was negative (FT $<0$ ), which was Rp 2,650,188 (Table 3), indicating that positive allowance on non-tradable inputs from the government to farmers occurred due to the implemented policies. It shows that the non-tradable input prices paid by farmers are lower than the actual non-tradable input prices.

The Nominal Input Protection Coefficient (NPCI) is a comparison between private tradable inputs costs and social tradable inputs costs, and is an bookmark that shows the degree of government patronage towards domestic input costs. The NPCI value of stevia farming in Tawangmangu Subdistrict, Karanganyar Regency was smaller than one $(\mathrm{NPCI}<1)$, which was 0.68 . It shows that the government had applied protective policies on tradable inputs, and stevia farmers received subsidies for tradable inputs, allowing them to buy the tradable inputs at lower prices. Tradable input costs paid by farmers amount to 68 percent of the traditional tradable input costs.

The NPCI value owned by stevia farming is in accordance with research conducted by Nurjanah et al. (2018), where less than one NPCI value $(\mathrm{NPCO}<$ 1) of sugarcane agriculture in Bantul was 0.44 . It shows that government policies were protective on the foreign input of sugar farming in Bantul regency. The impact of government policies was that farmers recieved subsidies for foreign inputs, allowing them to buy the foreign inputs at lower prices.

Based on the value of IT, FT, and $\mathrm{NPCI}$, the government policy on inputs is considered to be in favor of stevia farmers, in accordance with regulation No. 47/ Permentan/ SR.310/ 11/ 2018 issued by the Minister of Agriculture of the Republic of Indonesia concerning the distribution and the top price of a 
single item of subsidized manure in the agricultural sector in the 2019 budget. In other words, the government's policy towards inputs was beneficial for stevia farmers in Tawangmangu Subdistrict, Karanganyar Regency. This condition certainly can increase the competitiveness of stevia because more farmers will involve themselves in planting and developing stevia farming, which increases stevia productivity.

\section{Input-Output Policy}

Analysis of input-output policy is a joint analysis of input policies and output policies imposed by the government on farm inputs and outputs. The indicators used to determine the implemented input-output policies were Effective Protection Coefficient, Net Transfer, Profitability Coefficient, and Subsidy Ratio to Producers.

The EPC value of stevia farming in Tawangmangu District, Karanganyar Regency was more than one, which was 2.07 , indicating that farmers received positive incentives. Positive incentives indicate that farmers recieved subsidy on policies implemented by the government. This also shows that government policies support domestic production activities, meaning that government policies provide protection to domestic producers (farmers) who cultivate stevia intensively and thus it can increase the competitiveness of stevia itself. The EPC value owned by stevia farming is in accordance with research conducted by Saputro et al. (2017), that the EPC value of sugarcane farming in Central Java Province was 1.76 and in East Java Province was 1.86. EPC value more than one $($ EPC $>1)$ indicate that farmers receive positive incentives or subsidies from the policy.

Net Transfer (Net Transfer or NT) is private returns minus social returns. Net transfer (NT) of stevia farming in Tawangmangu Subdistrict, Karanganyar Regency was positive, which was Rp. 90,593,362 (Table 3). The NT value indicates that there is additional surplus received by producers due to the input and output policies applied by the government. This also means that the input-output policy implemented by the government protected stevia producers. The NT value owned by stevia farming is in accordance with research conducted by Nurjanah et al. (2018), where the positive NT value of sugarcane agriculture in Bantul is USD 10,697,503.47. This shows an incentive to increase production from the application of government policies applied to input and output factors.

Profitability Coefficient (PC) is a comparison among private net returns and social net returns. The value of PC stevia farming in Tawangmangu 
Subdistrict, Karanganyar Regency is more than one, which is equal to 3.15 . This value shows the profits received by farmers are higher than the profits that should be obtained at social prices since government policy provide incentives to stevia producers in Tawangmangu Subdistrict, Karanganyar Regency. The PC value owned by stevia farming is in accordance with research conducted by Nurjanah et al. (2018), where the PC value of sugarcane agriculture in Bantul was more than one, which was equal to 3.05. This shows that the government policy adopted increased profits, where the profit received personally (financially) was greater than 3.05 times the social (economic) benefit.

Subsidy Ratio to Producers (SRP) shows net incentives for revenue that are calculated at social prices. SRP stevia farming in Tawangmangu Subdistrict, Karanganyar Regency was positive, which is 1.06. It means that the implemented government policies so far have caused stevia farming to incur lower costs of 106 percent of the opportunity cost of production. Positive transfer values indicate that overall government policies or market distortions that occur benefit stevia farmers. It was because stevia farmers receive positive subsidies due to the applied policies. The SRP value owned by stevia farming is in accordance with research conducted by
Nurjanah et al. (2018), where the SRP value of sugarcane agriculture in Bantul is positive, which was equal to 0.44 . This shows that the the divergence between financial and economic excellence in sugarcane farming was about 44 percent of gross revenue, since sugarcane farmers received positive subsidies than if there were no government policy.

In this study, the input-output of stevia farming in Tawangmangu Subdistrict, Karanganyar Regency obtained incentives or protection from government policies. Stevia farmers received an output price that is higher than the actual price, and the price of private tradable inputs was lower than the actual price. This certainly will increase the benefits received by stevia farmers, thereby farmers grow stevia intensively and increased stevia production domestically. As a result, it affected the increasing competitiveness of stevia.

\section{CONCLUSIONS AND SUGGESTION}

Stevia farming in Tawangmangu Subdistrict, Karanganyar Regency is proven to have a competitive excellence and comparative excellence. The effect of government policy on output (stevia dried leaves) shows that the output price received by stevia farmers was higher than the price that should be, meaning that stevia farmers in Tawangmangu 
Subdistrict received protection from the government. The analysis on the effect of government policies on inputs shows that the cost of private tradable inputs was lower than the costs of non-tradable social inputs, so stevia farmers receive subsidies to obtain inputs at prices lower than the price they ought be. The analysis on the effect of government policy on input-output indicates that stevia farmers in Tawangmangu Subdistrict, Karanganyar Regency who cultivate stevia intensively received protection from the government. Thus, government policy benefited for stevia farmers, which will increase the competitiveness of stevia.

It is pivotal that the government provide the stevia farmers with stevia superior seeds to motivate the farmers in cultivating stevia intensively and to boost the production of high-quality stevia product. Besides that, stevia farmers are encouraged to sort between stevia leaves and stems. These efforts are needed so that farmers get better and farmers can be even more intensive in cultivating stevia, so stevia produced is of high quality.

\section{REFERENCES}

Abdalla Emam, A., \& Musa, O. M. (2011).
Production: A Study of Kenana Sugar Company, Sudan. Journal of Agricultural Science, 3(3), 202210. https://doi.org/10.5539/jas. v3n3p202

Ahmad,N.,Ahmad,N.,\&Rab,A.(2016).LightInduced Biochemical Variations in Secondary Metabolite Production and Antioxidant Activity in Callus Cultures of Stevia Rebaudiana (bert). Journal of Photochemistry and Photobiology B: Biology, 154, 51-56. https://doi.org/10.1016/j. jphotobiol.2015.11.015

Akhtar, W., Sharif, M., Qureshi, A. H., Aujla, K. M., \& Khan, M. A. (2016). Competitiveness of Tomato Production in Punjab, Pakistan. Pakistan J. Agric. Res., 29(2), 179188.

APPI. (2019). appi.pdf. Retrieved from www.appi.or.id/download. php?kat=statistic\&fileid=202

BPS. (2009). Tabel Input Output Indonesia Updating 2008 (Vol. 21). Jakarta.

Djajadi. (2014). Pengembangan Tanaman Pemanis Stevia rebaudiana (Bertoni) di Indonesia. Perspektif, 13, 25-33. 
Edi, B., Mardiani, D., \& Manul. (2015).

Panduan Budidaya Stevia sebagai Penghasil Gula Rendah Kalori. Bandung: Koperasi NUKITA.

Fedor, M. (2016). Global Stevia Market Passes $\$ 350$ Million. Retrieved from Zenith International Ltd website: https://www.zenithglobal.com/ar ticles/1818?Global+stevia+marke $\mathrm{t}+$ passes $+\% 24350+$ million

Gittinger, J. P. (1986). Economic Analysis of Agricultural Projects (2 Rev). Jakarta: The Economic Development Institute of the World Bank.

Hembrough, A. (2011). Stevia Sweetens Health Trends. Retrieved from Zenith International Ltd website: https://www.zenithglobal.com/ articles/753

Kurniawan, P., \& Budhi, M. K. S. (2017). Smart Leadership-Being a Decision Maker \#2. Andi Publisher.

Lemus-Mondaca, R., Vega-Gálvez, A., Zura-Bravo, L., \& Kong, A. H. (2012). Stevia Rebaudiana Bertoni, Source of a High-Potency Natural Sweetener: A Comprehensive Review on The Biochemical, Nutritional and Functional Aspects. Food Chemistry, 132(3), 1121-
1132. https://doi.org/10.1016/j. foodchem.2011.11.140

Magnuson, B. A., Carakostas, M. C., Moore, N. H., Poulos, S. P., \& Renwick, A. G. (2016). Biological Fate of LowCalorie Sweeteners. Nutrition Reviews, 74(11), 670-689. https:// doi.org/10.1093/nutrit/nuw032

Malian, A. H., \& Saptana. (2003). Dampak Peningkatan Tarif Impor Gula terhadap Pendapatan Petani Tebu. Bogor.

Monke, E. a, \& Pearson, S. R. (1989). The Policy Analysis Matrix for Agricultural Development. In Cornell University Press. https:// doi.org/10.1080/03768359 008439507

Nordiana, I., Wmn, W. N., Fatin, K., Nurwajihah, M. N., R, N. A., \& Asmah, A. (2016). Cost Effective on Production of Sugar's Substitute. 3(8), 5-8. https://doi. org/10.5281/zenodo.60343

Nurjanah,H.,Hardyastuti,S., \&Perwitasari, H. (2018). Competitiveness Analysis of Sugarcane Farming in Bantul. Proceeding of the 2nd International Conference on Tropical Agriculture, 95-108. https://doi.org/10.1007/978-3319-97553-5 
Purwadi, D., Ainuri, M., Kurniawan, M. P., \& Dermawan, A. B. (2010). Komersialisasi Produk Stevia ( Stevia Rebaudiana) sebagai Pemanis Alami Rendah Kalori. Proceeding Seminar Nasional APTA, 287-293.

Redwood, S., \& Crossland, N. (2014). Global Stevia Market Up 14\% in 2014. Retrieved from Zenith International Ltd website: https:// www.zenithglobal.com/articles/1 464?Global+Stevia+market+up+1 $4 \% 25+i n+2014$

Salvatore, D. (1997). Ekonomi Internasional Edisi Kelima Jilid 1 (Kelima; M. Haris, Ed.). Jakarta: Erlangga.

Saputro, W. A., Masyhuri, M., \& Suryantini, A. (2017). Analysis Competitiveness of Sugarcane Farming in Central Java and East Java. Agro Ekonomi, 28(2), 237-
251. https://doi.org/10.22146/ jae.27595

Sukayat, Y., Hapsari, H., Pardian, P., Supyandi, D., Rani, D. A. N., \& Bk, A. (2018). Keputusan Petani dalam Pengembangan Stevia di Daerah Pangkuan Hutan ( Kasus pada Kelompok tani Mulyasari Desa Cibodas Kecamatan Pasir Jambu Kabupaten Bandung ). Jurnal Ilmu Pertanian Dan Peternakan, 6, 3947.

Yadav, A. K., Singh, S., Dhyani, D., \& Ahuja, P. S. (2011). A review on the improvement of stevia [ Stevia rebaudiana ( Bertoni )]. Canadian Journal of Plant Science, 91(2067), 1-27. https://doi.org/10.4141/ CJPS10086 